University of Warwick institutional repository: http://go.warwick.ac.uk/wrap This paper is made available online in accordance with publisher policies. Please scroll down to view the document itself. Please refer to the repository record for this item and our policy information available from the repository home page for further information.

To see the final version of this paper please visit the publisher's website. Access to the published version may require a subscription.

Author(s): DAVID ARNOLD

Article Title: Plant Capitalism and Company Science: The Indian Career of Nathaniel Wallich

Year of publication: 2008

Link to published version: http://dx.doi.org/

10.1017/S0026749X0700296X

Publisher statement: None 


\title{
Plant Capitalism and Company Science: The Indian Career of Nathaniel Wallich*
}

\author{
DAVID ARNOLD \\ Department of History, University of Warwick, Coventry CV 4 7AL, UK \\ Email:d.arnold@warwick.ac.uk
}

\begin{abstract}
The career of the Danish-born botanist Nathaniel Wallich, superintendent of the Calcutta Botanic Garden from 1815 to 1846 , illustrates the complex nature of botanical science under the East India Company and shows how the plant life of South Asia was used as a capital resource both in the service of the Company's economic interests and for Wallich's own professional advancement and international reputation. Rather than seeing him as a pioneer of modern forest conservation or an innovative botanist, Wallich's attachment to the ideology of 'improvement' and the Company's material needs better explain his longevity as superintendent of the Calcutta garden. Although aspects of Wallich's career and botanical works show the importance of circulation between Europe and India, more significant was the hierarchy of knowledge in which indigenous plant lore and illustrative skill were subordinated to Western science and in which colonial science frequently lagged behind that of the metropolis.
\end{abstract}

\section{Introduction}

In a pioneering article twenty years ago, Marika Vicziany used the career of the English East India Company surgeon-naturalist Francis Buchanan to illuminate the multi-stranded relationship between science and empire in early nineteenth-century India. Although her primary concern was to question the objectivity of the socio-economic data collected by Buchanan during his Mysore and Bengal surveys, she ably showed the connection between Buchanan's professional and personal goals as a naturalist, the constraints Company service imposed on him and the political agenda that lay behind his roving

*A version of this paper was presented to the Royal Asiatic Society in February 2006. I published a brief account of Wallich in The Tropics and the Traveling Gaze: India, Landscape and Science, I80o-I856, Seattle, University of Washington Press, 2006, 149-56. 
commissions in south India and Bengal. ${ }^{1}$ In the years since Vicziany's article appeared the scholarly understanding of colonial science has become more complex and contested, not least in the degree of emphasis given to the ideological framing and political instrumentality of science and in the tensions between hierarchical and circulatory models of scientific knowledge and practice. ${ }^{2}$

The present essay follows Vicziany by assessing the Indian career of Nathaniel Wallich (1 786-1854), a Danish-born surgeon-botanist and Buchanan's successor as the superintendent of the Calcutta Botanic Garden. It thereby seeks to re-examine the relationship between science and empire under Company rule, and to use Wallich's career as a basis for examining the constitution of botany as a colonial science and the wider evaluation and exploitation of India it illustrates. In part Wallich's career is of interest precisely because it serves as an apparent antithesis to Buchanan's. For all his ambitions, Buchanan held the prized post of superintendent of the botanic garden in Calcutta for barely six months before being driven by ill health to leave India in October 1815 . For this reason, among others (including his failure to publish more than a fraction of the scientific data he had accumulated in India), he was, in Vicziany's estimation, 'ultimately [a] disappointed man', and she pointedly contrasted his professional failures and scientific frustrations with Wallich's 'more fortunate career'. ${ }^{3}$ Perhaps Wallich benefited, as she suggests, from Buchanan's 'cynical' advice and 'bitter' experience. ${ }^{4}$ Certainly, despite disadvantages of his own, Wallich was successful in ways that Buchanan was not-most evidently not only in his remarkably long tenure (from October 1815 to April 1846) of the superintendency of the Calcutta garden, one of the most

${ }^{1}$ M. Vicziany, 'Imperialism, Botany and Statistics in Early Nineteenth-Century India: The Surveys of Francis Buchanan (1762-1829)', Modern Asian Studies, 20: 4, $1986,625^{-60 .}$

${ }^{2}$ R. MacLeod, 'Introduction' to 'Nature and Empire: Science and the Colonial Enterprise', Osiris, 15, 2000,1-13; M. Harrison, 'Science and the British Empire', Isis, 96, 2000, 56-63.

${ }^{3}$ M. Vicziany, 'Imperialism', 626, 655. She writes of N. Wallich's 'long, easy and productive career', claiming that he was not asked to complete Buchanan's Bengal survey 'because he lacked the talent for such a complex task' (ibid., 655). But Wallich thought the 'tedious' and 'repetitive' survey fit only for reference: N. Wallich, 13 August 1832, 'Minutes of Evidence taken before the Select Committee on the Affairs of the East India Company', Parliamentary Papers, 1832, (Cmd 735: II), 194. Even so Wallich regarded Buchanan as a 'very dear friend' and visited him in Scotland in October 1828 shortly before his death. N. Wallich to W. Hooker, 16 September 1828, Director's Correspondence (DG) 43, Royal Botanic Gardens (RBG), Kew.

${ }^{4}$ M. Vicziany, 'Imperialism', 637,656 . 
prestigious scientific appointments in the extra-European world at the time, but also in bringing his botanical labours to international attention through the distribution of the Wallichian herbarium in the late 1820 s and the publication of the three sumptuously illustrated volumes of his Plantae Asiaticae Rariores between 1830 and 1832 .

But, while Wallich's name has long been remembered by botanists, ${ }^{5}$ and continues to be commemorated by association with a large number of South and Southeast Asian plant species, he barely figured-until recently-in most historical accounts of nineteenth-century India. However, with the growth of scholarly interest in the history of science and environment in colonial South Asia over the past twenty years, Wallich has emerged as a figure of some prominence. It is now argued that he did much to promote the conservationist cause by drawing attention to the rapid destruction of Indian and Burmese forests, by proposing state regulation of the remaining forests to save them from over-exploitation and by establishing plantations to raise teak, bamboo and sissoo (Dalbergia latifolia). Even though his efforts to influence state policy in favour of conservation ultimately proved futile, Wallich was, in Richard Grove's judgement, 'precocious', 'a conservationist voice crying in the wilderness'. Further, in his view, 'Wallich brought about a distinctive "social forestry" based on indigenous precedents and apparently concerned for the basic needs of the poorer rural communities'. ${ }^{6}$ However, Wallich's standing as a 'green imperialist' (if by that slippery expression is meant an affirmative engagement with environmental, especially conservationist, issues) calls for critical reconsideration. His advocacy of forest regeneration, too often treated in isolation, needs to be placed within the context of his career both as an aspiring naturalist and a loyal servant of the East India Company. His forest schemes, like much of his botany, can best be understood not within a conservationist paradigm but as part of an imperial

${ }^{5}$ I. H. Burkill, Chapters on the History of Botany in India, Delhi, Government of India, Manager of Publications, India, 1965; R. Desmond, The European Discovery of the Indian Flora, Oxford, Oxford University Press, 1992; C. R. Fraser-Jenkins, The First Botanical Collectors in Nepal: The Fern Collections of Hamilton, Gardener and Wallich, Dehra Dun, Bishen Singh Mahendra Pal Singh, India, 2005.

${ }^{6}$ R. H. Grove, Green Imperialism: Colonial Expansion, Tropical Island Edens and the Origins of Environmentalism, I60o- I860, Cambridge, England, Cambridge University Press, 1 995, 41 1, 413, 415, 418; Cf. K. Sivaramakrishnan, Modern Forests: Statemaking and Environmental Change in Colonial Eastern India, Stanford, CA, Stanford University Press, 1999, 109-10. 
concern with exploiting India's material 'riches' and implementing 'improvement' ideology. The point is not simply to present botany (and forestry) as an adjunct to imperialism, a connection made many times before, ${ }^{7}$ nor simply to question imperialism's 'green' credentials, but rather to show how plants were a versatile resource, situated within the 'volatile nexus' of science, commerce, state politics (and, one might add, personal ambition), and how, in the process, India itself was commodified and marketed. ${ }^{8}$ In seeking to establish the 'cultural constitution' of botany as a colonial science, ${ }^{9}$ we should not lose sight of its commercial underpinnings.

There is a further issue in seeking to decipher Wallich's long career. As a leading botanist of the Company period, Wallich has been hailed as one of those 'widely recognized scientific geniuses', that 'galaxy of naturalists', whose contribution to science, though largely made in India, was yet held in high international regard. ${ }^{10}$ Such an interpretation of Wallich (and others in that select company) contests any simplistic demarcation between innovative and authoritative science as practised in the metropolis and an inferior, more empirically oriented, science pursued in the colonies. ${ }^{11}$ It further supports the view that between Britain and India in the early nineteenth century scientific ideas, practices and careers circulated with relative freedom, as partners in the co-constitution of science. ${ }^{12}$ But it can, more cautiously, be argued that, while Wallich's career demonstrates the importance of scientific itineration and the circulation of plants and

${ }^{7}$ L. H. Brockway, Science and Colonial Expansion: The Role of the British Royal Botanic Gardens, New York, Academic Press, 1979; R. Drayton, Nature's Government: Science, Imperial Britain, and the 'Improvement' of the World, New Haven, CT, Yale University Press, 2000.

${ }^{8}$ L. Schiebinger and C. Swan, 'Introduction', in L. Schiebinger and C. Swan (eds), Colonial Botany: Science, Commerce, and Politics in the Early Modern World, Philadelphia, PA, University of Pennsylvania Press, 2005, 2.

${ }^{9}$ K. Philip, 'English Mud: Towards a Critical Cultural Studies of Colonial Science', Cultural Studies, 1 2: 3, 1998, 300-31.

${ }^{10}$ S. Sangwan, 'Natural History in Colonial Context: Profit or Pursuit? British Botanical Enterprise in India, 1778-1820', in P. Petitjean et al. (eds), Science and Empires, Amsterdam, Kluwer, 1992, 289.

${ }^{11}$ S. Sangwan, 'From Gentlemen Amateurs to Professionals: Reassessing the Natural Science Tradition in Colonial India, 1780-1840', in R. H. Grove, V. Damodaran and S. Sangwan (eds), Nature and the Orient: The Environmental History of South and Southeast Asia, Delhi, Oxford University Press, 1998, 227.

${ }^{12}$ Cf. K. Raj, 'Circulation and the Emergence of Modern Mapping: Great Britain and Early Colonial India, 1764-1820', in C. Markovits, J. Pouchepadass and S. Subrahmanyam (eds), Society and Circulation: Mobile People and Itinerant Cultures in South Asia, I750-1950, New Delhi, Permanent Black, 2003, 23-54. 
other objects mobilised through botany's material culture-within imperial Asia as well as between metropole and colony-it also shows how Europe remained, in many vital respects, the undisputed centre of scientific authority and esteem, the principal source of scientific innovation and the ultimate marketplace for India's plant 'riches', and hence the difficulties experienced by Wallich (and others) in commanding an international reputation except via Europe.

\section{Plants, Patrons and Preferment}

There are several reasons why Wallich's career might be considered atypical. Firstly, he was a Dane. Born in Copenhagen on 28 January 1786, he received a diploma from the Danish Academy of Surgeons in 1806 . He arrived in India in 1807 as an assistant surgeon at the Danish enclave of Serampore, fourteen miles from Calcutta. A year later, in $\mathbf{1 8 0 8}$, with the resumption of the Napoleonic Wars, the British annexed Serampore and Wallich found himself a prisoner of war. Released on parole, he was admitted as an assistant surgeon in the service of the English East India Company, though this appointment was not confirmed until May 1814. In commending Wallich (in a suitably materialistic turn of phrase) as a valuable 'acquisition', William Roxburgh, as superintendent of the Calcutta Botanic Garden, remarked that he was 'not only willing, but anxious' to be transferred from Serampore to the garden; he had already 'made himself acquainted with our late discoveries in the vegetable Kingdom', and so might be 'advantageously employed ... in exploring the unknown productions in Botany, as well as Zoology, and Mineralogy, still abundantly diffused over the Honourable Companies [sic] Territories'. ${ }^{13}$

Like many entrants to the Company's medical service, medicine was not Wallich's principal passion nor the most promising route to his advancement. ${ }^{14} \mathrm{He}$ almost entirely gave up medicine and devoted

${ }^{13}$ W. Roxburgh to Secretary, Public Department, 24 February 1809 , Bengal Public Consultations (BPC), no. 26, 10 March 1809, India Office Records (IOR), British Library, London.

${ }^{14}$ Wallich gave up a medical practice worth Rs 300 to 400 a month in Serampore in order to enter the East India Company's service and advance his botanical career, declaring that 'his object was knowledge \& not money': W. Roxburgh to Secretary, Public, 24 February 1809 , BPC, no. 26, 10 March 1809. 
himself, as Roxburgh's assistant, to botany. ${ }^{15}$ In October 1815 , at the age of 29, he became the officiating superintendent of the garden, and was confirmed in that post in August 1817. This was no mean position: not only was the garden 'the noblest and most beautiful of its kind in the world', ${ }^{16}$ but the superintendent was one of the government's chief scientific agents and advisers. He was also, by Company standards, reasonably well paid. In addition to his surgeon's pay and other allowances, Wallich received the 'munificent but not extravagant' monthly salary of Rs. 15 oo as superintendent (worth $£_{1} 87$-1 os at the time). ${ }^{17}$ Even after retrenchment in 1830 cut funding for the garden's establishment (from Rs. 1600 to Rs. 1100 a month), he still oversaw a staff of some 200 gardeners, clerks and plant collectors. ${ }^{18}$ When Wallich retired to London in April 1846 it was on a modest pension of $£_{3}$ OO a year, but this, supplemented by his wife's inheritance of $£ 20$,ooo, allowed him and his family to live in relative comfort in Upper Gower Street.

Yet even if the manner of Wallich's entry into the service of the East India Company was unconventional, much else was not. In India (as elsewhere in the Empire) there were many individuals not British by birth who entered imperial service and who rose, like Wallich, to positions of authority. There were, for instance, several Germans in the Indian Forest Department in the late nineteenth century, three of whom served in succession as inspectors general. ${ }^{19} \mathrm{~A}$ number of naturalists in India in the late eighteenth and early nineteenth centuries were of continental European origin, including Johan König, a Baltic German who worked at the Danish enclave of Tranquebar in south India before being appointed as a naturalist to the Madras government in 1778 . Under the influence of their adviser Joseph

${ }^{15}$ It is, though, indicative of the multi-skilling expected of Company servants that in 1827 Wallich had to cut short his botanical mission to Burma to conduct a post-mortem in a legal case in Calcutta: N. Wallich to C. Lushington, Secretary, Bengal Public, 25 June 1827, Board's Collections (BC) F/4/1068: 29180, IOR.

${ }^{16} \mathrm{~N}$. Wallich to Secretary, General Department, 1 October $1836, \mathrm{BC} \mathrm{F} / 4 / 1761$ : 72126.

${ }_{17}^{17}$ J. H. Stocqueler, The Hand-Book of British India, London, W. H. Allen, $1854,169$.

18 But, as Wallich's successor, H. Falconer, observed that, despite the superintendent holding 'a leading position in the metropolis of the Government', his salary was less than the Apothecary General's. 'Memorandum on the Calcutta Botanical Garden' (n.d.), in India: Calcutta Botanic Garden, I830-1928, Royal Botanic Gardens, Kew.

${ }^{19}$ R. Rajan, 'Imperial Environmentalism or Environmental Imperialism? European Forestry, Colonial Foresters and the Agendas of Forest Management in British India, 1800-1900', in R. H. Grove et al. (eds), Nature and the Orient, 343-51. 
Banks (whose position epitomised the continuing hold of London over Company patronage and decision making), the Court of Directors seemed disposed to believe that Germans and Scandinavians made better botanists than their British contemporaries, closer in training and aptitude to the great Swedish naturalist Carl Linnaeus. ${ }^{20}$ That Wallich had been taught botany at the University of Copenhagen by Martin Vahl, a correspondent of Linnaeus, and subsequently by J. W. Hornemann, and maintained contact with numerous Continental naturalists, aided his rapid rise and continuing prominence in India. But it was particularly through Banks that Wallich was appointed a superintendent of the Calcutta garden. Wallich never met Banks (who died in 1820) but, in the first of many such transactions, he repaid his distant benefactor by sending him plants for Kew Gardens. Plants, patronage and preferment mingled in Wallich's career from the outset.

A second, perhaps more compelling, reason to consider Wallich's career exceptional is that he was the son of a Jewish merchant. It has been suggested that it was for this reason that he was obliged to enter Denmark's overseas (rather than domestic) medical service and, further, that anti-semitic prejudice blighted his early career and made his advancement unpopular-at least among nonnaturalists. ${ }^{21}$ For two years Wallich was embroiled in a fierce contest for control of the Calcutta garden after Buchanan's departure and was only confirmed as superintendent in 1817. Wallich's career was strewn with bitter disputes-with high-ranking officials, fellow botanists and head gardeners-yet he seems never to have cited antisemitism as the cause of the attacks he suffered, even though he wrote bitterly in his correspondence about the many assaults on his reputation, once observing that 'few men have had more inflictions from false and treacherous friends than I have'. Relationships with colleagues and protégés, begun with protestations of gratitude and respect, ended with 'daggers stuck into my unsuspecting back from behind'. ${ }^{22}$ He particularly recalled the 'fierce and fiendish scandal in the Calcutta papers' in 1815 , when he was denounced as unfit to run the botanic garden. ${ }^{23}$ But, without more conclusive evidence, it is hard to determine what part anti-semitism played either in the

${ }^{20}$ Grove, Green Imperialism, 331.

${ }^{21}$ S. Sangwan, 'Gentlemen Amateurs', 226.

${ }^{22}$ N. Wallich to W. Hooker, 12 February 1853 , DC 55 , RBG.

${ }^{23}$ N. Wallich to G. Bentham, 6 December 1849 , Bentham Correspondence, RBG. 
recurrent criticism of Wallich or in shaping his deep-felt need for social acceptance and professional recognition.

There is a history to be written of anti-semitism in colonial India. A conspicuous example is that of the Russian Jew and French-trained bacteriologist, Waldemar Haffkine, who developed anti-cholera and anti-plague sera in the 1890 and 1900 in Bombay, but whose career was shattered in 1902 by the vituperative and unsubstantiated claims of professional incompetence levied against him. ${ }^{24}$ Wallich may have been subjected to similar prejudice, though unlike Haffkine, who became increasingly committed to the Jewish faith, by the time he reached India (and probably well before) Wallich had abandoned Judaism and sought assimilation into Christian society. In 1812 he married a young Danish woman, Julia Maria Hals, at Serampore. In 1815 , after his first wife's death, he wed Sophia Collins, a Bengalborn English woman with family connections in Yorkshire. So far had Wallich's social geography shifted that even before he made his first visit there in 1828 , he followed Anglo-Indian convention by referring to England as 'Home'. ${ }^{25} \mathrm{He}$ attended church in Calcutta and London; he and his children were buried in Christian cemeteries. His son George, born in Bengal but schooled in Britain, received an MD from Edinburgh University before joining the Bengal Medical Service and making his name as a marine zoologist. One of Wallich's daughters, Hannah, married a captain in the Bengal Army. Two of his nephews from Copenhagen also joined him in Calcutta: Charles Cantor, a banker, advised Wallich on his investments and saved him from financial loss when the Union Bank collapsed in the 1840s; the other, Theodore Cantor, joined the Bengal Medical Service in 1835 and became a naturalist. By the 1830 s, Wallich had himself become something of an establishment figure, enjoying an 'extended acquaintance with Calcutta Society'. ${ }^{26}$

The patronage Wallich received and dispensed is essential in understanding his Indian career. At Serampore he became a close friend of the Baptist missionary William Carey, whom he later described as 'one of the most extraordinary men who ever came to

${ }^{24}$ E. Lutzker, 'Waldemar Mordecai Haffkine', in Haffkine Institute Platinum Jubilee Commemoration Volume, I899-1974, Bombay, Haffkine Institute, 1974, 11-9.

${ }^{25} \mathrm{~N}$. Wallich to W. Hooker, 1 January 1828 , DC 43 . However, Wallich remained attached to Denmark (still his 'native country' in 1819), including seeking permission to wear the insignia of the Danish order of Dannebrog: BC F/4/75 1: 20525.

${ }^{26}$ T. Thomson, 'Report on the Hon'ble Company's Botanic Garden', 23 July 1856 , in Calcutta Botanic Garden, I855-I89o. 
India, both as a missionary . . . and a botanist and agriculturist' ${ }^{27}$ They had a keen mutual interest in plants and 'improvement' (though not perhaps, in Wallich's case, in the Christian view of nature as God's works). The early mentoring that Wallich received from Carey and Roxburgh did much to shape the 'improving' agenda and materialistic approach to botany that Wallich subsequently brought to the Company's service. Until Carey's death in 1834 , he and Wallich were close collaborators: they oversaw the posthumous publication of Roxburgh's Flora Indica (in two volumes, 1820 and 1824, the latter with extensive additions by Wallich), they served together on the government committee that recommended sissoo plantations and they cooperated in the Agricultural and Horticultural Society of India which Carey founded in 1820 . When in 1819 , at a time of financial difficulty, Wallich offered his extensive botanical library to the Company for Rs. 8506 ( $1_{1063)}$ Carey was one of the two men appointed to assess its value and approve its purchase. ${ }^{28}$ But Carey functioned, too, as one of Wallich's principal patrons, notably in using his influence with the Calcutta establishment to secure his friend's appointment to the botanic garden. ${ }^{29}$

Carey was not the only individual on whose support Wallich could rely. There were at least two others whom he regarded as his particular patrons. One was Henry Thomas Colebrooke. A leading government servant, Orientalist and member of the Asiatic Society of Bengal (in which Wallich was also active), Colebrooke had a longstanding interest in 'improvement' and held temporary charge of the botanic garden following Roxburgh's departure in 1815. In the Plantae Asiaticae Rariores, in which he memorialised many of his friends, Wallich described Colebrooke as 'the best friend and patron I ever possessed in the world', an individual 'to whom I am under far greater obligations than to any man living, and whose name it is impossible for me to mention without emotions of the warmest gratitude and respect'.${ }^{30}$ Another 'benefactor and patron' to whom he

${ }^{27}$ N. Wallich, 'A Brief Notice Concerning the Agricultural and Horticultural Society of India', Hooker's Journal of Botany, 5, $1853,137$.

${ }^{28} \mathrm{~N}$. Wallich's library contained 538 volumes, including some of the most prized works of Indian botany: BC F/4/624: 15931 .

${ }^{29}$ D. Kumar, 'The Evolution of Colonial Science in India: Natural History and the East India Company', in J. M. MacKenzie (ed.), Imperialism and the Natural World, Manchester, Manchester University Press, 1990, 52-3.

${ }^{30}$ N. Wallich, Plantae Asiaticae Rariores: Or Descriptions and Figures of a Select Number of Unpublished East Indian Plants, vol. 1, London, Trettel, Wartz and Richter, 1830, 36. 
paid equally effusive, if less public, tribute was Sir George Nugent who in 1814-1815, as Commander-in Chief of the Indian Army and Vice President of the Governor-General's Council, ordered Wallich to remain in Calcutta rather than join the army assembling for war in Nepal and so made it possible for him to fill the vacancy at the botanic garden. It was through his intervention, Wallich later recalled, that he acquired 'the appointment which I held during near 32 years'. 31

At some stage, probably after leaving Serampore, Wallich became a freemason. There was nothing exceptional in this. Freemasonry was rife in early nineteenth-century India: Calcutta alone had eight Masonic lodges in the 1820 s (even Serampore boasted one). It flourished under Lord Hastings, when he was the Governor General (and 'Grand Master of India') from 1813 to 1823 , and his successor Lord Amherst (1823-1828), and was widespread among the clergy, judiciary and mercantile communities. Sir Edward Ryan, a Chief Justice in Calcutta and President of the Asiatic Society of Bengal, was another friend and leading light, as was the soldier-botanist, William Munro. ${ }^{32}$ Freemasonry may have enabled Wallich to establish ties with local patrons; it surely helped cement his professional position and facilitate his incorporation into Calcutta's European elite.

One of the striking aspects of Wallich's career was his longevity. By this is not principally meant his relatively long life (he died in April 1854, aged 68), though he lived longer than most European botanists in India, many of whom perished before their late thirties. ${ }^{33}$ More extraordinary, though, was his thirty-year tenure as the superintendent of the Calcutta Botanic Garden. Few Europeans in nineteenth-century India occupied such a prestigious and influential position for so long. That Wallich survived in high office for three decades, in the face of frequent hostility, even contempt, does appear remarkable. There was, though, something contradictory about Wallich's character and professional standing. For all his apparently

${ }^{31}$ N. Wallich to Munro, 16 October 1848 , Munro Correspondence, RBG.

${ }^{32}$ W. K. Firminger, The Early History of Freemasonry in Bengal and the Punjab, Calcutta, Thacker, Spink and Co., 19o6, ch. 8, and idem, The Second Lodge of Bengal in the Olden Times, Calcutta, Thacker, Spink and Co., 1911. Wallich's involvement in freemasonry is most evident from Wallich to Munro, 11 February 1848, Munro Correspondence.

${ }^{33}$ D. Arnold, Tropics, 61-70. However, even in the late 1820 s, Wallich thought of himself as suffering from 'old age': N. Wallich to W. Hooker, 7 May 1829, DC $5^{2}$, RBG. 
argumentative nature, Wallich was seen by many of those close to him, the recipients of his patronage and encouragement, as having a 'congenial spirit' and displaying 'great kindness and warmth'. ${ }^{34}$ To his superiors he could be a dedicated, practically minded, employee as well as an accomplished naturalist. He was frequently praised in government despatches for his 'zeal, perseverance and scientific discernment'. ${ }^{35}$ His views on the need to protect the forests of India and Burma were regarded by the Government of India as 'judicious', and in 1825 Lord Amherst commended his role as the secretary of the Plantation Committee (despite a bitter dispute with other members of the committee that nearly wrecked its deliberations) as 'additional proof of his activity, energy and assiduous research'. 36

Dismissed by the French naturalist Victor Jacquemont as 'a rather inferior Danish botanist', ${ }^{37}$ Wallich long continued to command official support and high regard. Even in the 1840 , when his reputation was fast losing its lustre, Wallich's work at the botanic garden was considered by the government of Lord Auckland (18361842 ) to be 'highly creditable'. Wallich himself believed that his work as a secretary of the Tea Committee in the late 1830 s and early 184 os was of 'high national importance' and that he had earned his honours 'by dint of intense bodily as well as mental labours ... exerted much beyond what had heretofore been considered as the sphere of duties of the Superintendent of this garden' ${ }^{38}$ His role as a superintendent was also commended by many of Calcutta's leading inhabitants and visitors-by Bishop Reginald Heber (who praised his 'frankness, friendliness and ardent zest for the service of science') and by Emily Eden, Lord Auckland's sister, for whom he obligingly laid out a garden at Barrackpore. ${ }^{39}$ It should be noted, though, that the botanic

${ }^{34}$ I. H. Burkill, 'William Jack's Letters to Nathaniel Wallich, 1819-182 1', Journal of the Straits Branch of the Royal Asiatic Society, 73, 1916, 149, 223.

${ }_{35}$ Bengal Public Letter, 1 April 1822 , BC F/4/7 1 2: 19459.

${ }^{36}$ Bengal Public Letter, 31 July 1820, BC F/4/655: 18040 ; minute of the Governor General in Council, 22 December 1825 , BPC, no. 70, December 1825 .

${ }^{37}$ V. Jacquemont to V. de Tracy, 1 September 1829 , Letters from India, I 829-I 832, London, Macmillan, 1936, 14 .

${ }^{38}$ N. Wallich to Secretary, Government of India, 30 September 1840; Lord Auckland to Court of Directors, 21 June 1841, BC F/4/1949: 84713.

${ }^{39}$ R. Heber, Narrative of a Journey through the Upper Provinces of India, $3^{\text {rd }} \mathrm{ed}$, vol. 1 , London, John Murray, 1828, 54; E. Eden, Letters from India, vol. 1, London, Richard Bentley, 1872, 1 70; E. Eden, Letters from India, vol. 2, London, Richard Bentley, 1872, 53 . 
garden was valued not merely as a renowned scientific institution, but also a public pleasure ground, frequented by Calcuttans seeking escape from the city's heat and bustle. Wallich survived for as long as he did partly by being an obliging courtier and industrious state servant as well as an accomplished botanist.

\section{The Wealth and Poverty of India}

Ever since the Bengal famine of 1770 , there had been an ongoing debate about the wealth and poverty of India. This debate took many forms, including critical scrutiny and spirited defence of the Company's commercial and revenue policies. One strand of this debate was to argue that India, despite the opulence of its former rulers and the seeming natural abundance of its well-watered provinces, was in actuality a poor country, by nature deficient in its climate, soil and vegetation. ${ }^{40}$ More commonly, it was claimed that India's poverty was more apparent than real-that it had suffered the recent effects of despotism, war and rapacity and the long-term consequences of poor husbandry and outmoded agricultural technique. ${ }^{41}$ Its true wealth could thus be realised under enlightened and peaceful rule and, more especially, through a regime of agrarian 'improvement'. ${ }^{42}$ One of the original functions of the Calcutta Botanic Garden, as conceived by its founder, Colonel Robert Kyd, in the 178 os was to compensate for the defective state of Indian agriculture by introducing and disseminating plants that would prevent the recurrence of major famines like that of 1770 , as well as contributing (as Banks also anticipated) to the growth of British commerce and manufacturing. ${ }^{43}$ After Kyd's departure superintendents of the Calcutta garden were often attracted to more

${ }^{40}$ Stocqueler, Hand-Book, 19-20.

${ }^{41}$ As by Buchanan in south India following Tipu Sultan's defeat: M. Vicziany, 'Imperialism'; D. Arnold, Tropics, 83-7. For Wallich's views on 'native misrule' in Burma see J. Crawfurd, Journal of an Embassy from the Governor General of India to the Court of Ava, 2nd ed, vol. 1, London, Henry Colburn, 1834, 219.

${ }^{42}$ D. Arnold, "Agriculture and "Improvement" in Early Colonial India: A PreHistory of Development', Journal of Agrarian Change, 5: 4, 2005, 505-25.

${ }^{43} \mathrm{~K}$. Biswas, The Original Correspondence of Sir Joseph Banks Relating to the Foundation of the Royal Botanic Garden, Calcutta, Calcutta, Royal Asiatic Society of Bengal, 1950; A. P. Thomas, 'The Establishment of the Calcutta Botanic Garden: Plant Transfer, Science and the East India Company, 1786-1806', Journal of the Royal Asiatic Society, 16: 2, 2006, $165^{-77}$. 
narrowly scientific concerns, but they did not entirely lose sight of these utilitarian objectives. Redressing what John Forbes Royle, a onetime protégé of Wallich's and former superintendent of the Company garden at Saharanpur, called the 'unaccountable discrepancy' between the natural wealth of India's soil and the poverty of its agricultural products remained a personal goal of individual botanists as much as (at times even more than) a Company objective. ${ }^{44}$

Wallich knew how to appeal to the Company's material interests. For all its 'munificence' as a patron of science, the Company was still (until 1833) a commercial enterprise and to a degree Wallich's professional engagement with botany reflected that mercantile orientation. On several occasions, as in the evidence he gave before a parliamentary Select Committee in 1832 (in the run-up to the renewal of the Company charter), Wallich stressed the immense, but as yet underexploited, material assets India possessed. Asked to explain his role as a superintendent of the Calcutta garden, he summarised his involvement in economic botany, forestry and 'the resources connected generally with those objects', including medicinal drugs, ${ }^{45}$ dyestuffs, cotton, silk, coffee, sugar and tea. Being forced to explain why India was not more productive, he replied that even though India was 'equal to any other part of the world in point of fertility and abundance of produce', its modes of tillage and husbandry were 'primeval'. Asked about the 'extreme poverty' of the people, he remarked that the peasants would not exert themselves; they toiled only for their daily sustenance and were satisfied with a minimal profit. The solution lay, he believed, in educating 'the natives', thereby 'bringing them to a higher state of civilization'. ${ }^{46}$ India was capable of producing 'every article which can conduce to the happiness of man': it only required 'skill and ingenuity and encouragement both to the natives and to Europeans' to make the country yield 'everything that can possibly be desired'. ${ }^{47}$ But Indians left too much 'to the spontaneous operations of

${ }^{44}$ J. F. Royle, Essay on the Productive Resources of India, London, W. H. Allen, 1840, iii-iv.

${ }^{45}$ For N. Wallich's plan to establish a physic garden in Calcutta, see Bengal Public Letter, 3 August 1826, BC F/4/955: 27123.

${ }^{46}$ N. Wallich, 13 August 1832, 'Minutes of Evidence taken before the Select Committee on the Affairs of the East India Company', 193-5.

${ }^{47}$ N. Wallich 14 August $183_{2}$, Ibid., 205-6. 
bountiful nature, unaided by ... human skill or industry'. ${ }^{48}$ They were 'the most improvident of the whole human race'. ${ }^{49}$

To a degree, Wallich was simply reiterating a view of India's value to British commerce and industry previously expressed by Banks, Kyd and Roxburgh. This was no doubt the kind of argument the Company would want to be presented to parliament in support of its Indian privileges and in defence of its 'civilising' mission. But Wallich was doing more than slavishly serving his masters. He appears consistently to have believed in the intimate connection between botany and capitalism, and in the concurrent advance of civilisation and science. As noted earlier, Wallich was involved from the outset with the Agricultural and Horticultural Society, set up by Carey in $1820 .{ }^{50}$ For thirty years Wallich extolled the society's work as supplementing that of the botanic garden in introducing and disseminating 'useful' and 'ornamental' plants from other tropical and temperate regions, in gathering horticultural and agricultural intelligence and in conducting trials on new varieties of sugar, cotton and other commercial crops-all at little cost to the government. A further virtue of the society was that it served a trans-racial clientele: in addition to its European members, it supplied seeds and plants to 'improving' zamindars and to 'the humbler classes of natives, cultivators, market-gardeners, etc.' in Calcutta and across eastern India. ${ }^{51}$

Cultivation, in Wallich's mind, was closely identified with the moral as well as material benefits of civilisation. Challenged in the 1830 , at a time of retrenchment, to justify the continuation of the botanic garden, he replied that 'No enlightened Government, least of all the British in this Country, can fail appreciating the beneficial influence which must result to the Governed from imparting to them a taste for agriculture and gardening-of all the human occupations the most pure, useful and Civilized'. By distributing thousands of plants, the garden had already 'effected a complete change among the natives of Bengal'. Years earlier there had been few gardens; now 'Country seats have arisen in all directions, gardens have been attached to

${ }^{48}$ N. Wallich to Secretary, Agricultural and Horticultural Society, 9 September 1823. Transactions of the Agricultural and Horticultural Society of India, Part I, 1829, 75 .

${ }^{49} \mathrm{~N}$. Wallich, 14 August 1832, 'Minutes of Evidence taken before the Select Commitee on the Affairs of the East India Company', 200.

${ }^{50}$ D. Arnold, 'Agriculture', 514-8.

${ }^{51}$ N. Wallich, 'Brief Notice', $13^{8-9}$. 
the houses in town, in the suburbs and on the banks of the River [Hooghly], both among the natives and Europeans, all replete with the choicest fruits and flowers'. This growth in 'civilised' taste was more than ornamental: it presaged a 'decided amelioration' in the countryside. One illustration of this (and of the 'high degree of utility' of the garden that supplied them) was the spread of fruit trees. Instead of 'miserable half wild' mangoes and peaches, fruit from the 'best grafted sorts' was now sold in Calcutta while exotics like the 'Otaheite apple' and 'Alligator pear' had been introduced. Wallich concluded that Calcutta's botanic garden, far from being confined to 'matters of a purely scientific nature', had been responsible for the 'extraordinary impulse which the agriculture of the Country has derived from the progressive extension of Knowledge and Civilization'. ${ }^{52}$

Wallich further elaborated on his understanding of the role of economic botany in the early 1820 s in seeking the government's permission to give his professional advice on the commercial growing of coffee in India. Coffee had been grown experimentally at Calcutta's botanic garden, but he saw its cultivation on a commercial scale as most 'desirable' and of 'great national interest'. ${ }^{53}$ A similarly mercantile outlook lay behind the formation of the Tea Committee in the late 1830 s with Wallich as its secretary. The Governor General, Lord Auckland, hoped that as a result of its labours private enterprise would take up tea cultivation in Assam and thereby attract 'the profitable investment of Capital from England'. The government would help to encourage and facilitate entrepreneurship but could not be expected to fund or to seek direct financial rewards from it: 'The real profit to Government will be in the general improvement of the province and the extension of Commerce. 54

Further evidence of how Wallich understood the triangular relationship between botany, capitalism and the Company lay in his approach to the timber supply question. For years the Company had been alarmed at dwindling supplies of Indian teak, which had been heavily exploited for shipbuilding and construction purposes. Under Roxburgh several plantations had been established in eastern India to counter this deficiency, but the teak trees were slow growing while the needs of the Company were increasingly urgent. ${ }^{55}$ Shortly after

${ }^{52}$ N. Wallich to Secretary, General, 1 October $1836, \mathrm{BC}$ F/4/1761: 72126.

${ }^{53}$ N. Wallich to C. Lushington, 7 February 1822, BC F/4/7 1 2: 14960.

${ }^{54}$ Lord Auckland, 19 July 1 839, BC F/4/1 794: 73768.

${ }^{55}$ For the fate of these plantations, see BC F/4/2648: 172113 . 
becoming superintendent, Wallich took up the issue. His immediate concern, though, was less with teak than with the declining availability of other sources of timber-notably sissoo, which Wallich, commending its rapid growth and ease of cultivation, described as 'among the most valuable and desirable trees in India' ${ }^{56}$ Conservation as a scientific and ecological goal was not Wallich's concern, nor was 'social forestry', but this was an instance where the military needs and revenue interests of the Company overrode those of private capitalists. He felt impelled to urge state intervention by the rapid loss and often wasteful methods of extraction employed by private (mainly Indian) contractors of trees whose timber was invaluable for 'public purposes' (meaning the needs of the state, not those of society at large) and whose continuing supply was intimately bound up with 'the prosperity of a most important branch of the Public Service', i.e. the Ordnance Department. Wallich argued that tough and durable sissoo timber was an ideal substitute for teak (and English oak) in the construction of gun carriages; its continuing availability was thus a matter of 'absolute necessity' to the military arm of the Company state. He favoured a three-pronged approach: measures to conserve or take over existing stands of sissoo, the creation of state-run plantations where sissoo trees, raised from seed, would be maintained for thirty years until their timber was fit for use and the surreptitious leasing of land in Awadh and Nepal to augment supplies from the Company's own territories. ${ }^{57}$

Initially the government appeared favourable to Wallich's strategy, appointing him the Superintendent General of Plantations and in 1823 establishing a Plantation Committee, of which he was the secretary as well as a member. However, although it met several times and produced ten interim reports, the 'Sissoo Committee' failed to initiate a new forest or timber-procurement policy. The government became alarmed at the heavy long-term expenditure involved in maintaining plantations and uneasy about the requisition or renting of land in ways that might infringe zamindari rights or offend the courts of Awadh and Nepal. Suitable land for nurseries and plantations proved hard to find, and the committee was wound up in 1827 , still pleading for more information to be gathered about Indian

${ }^{56}$ N. Wallich to Secretary, General, 25 May 1820 , BG F/4/655: 18040.

57 See the reports of the Plantation Committee, especially 26 June 1823, BPC, 17 July 1823 , nos. 33-39. 
timber trees. ${ }^{58}$ Having toured the recently conquered lower provinces of Burma in 1826-1827, whose forest resources he believed would 'unquestionably form an acquisition of great value', Wallich advanced similar arguments about the need to protect Burmese teak and other timber trees from ruthless private exploitation. ${ }^{59}$ Again, revenue and military interests were uppermost in his mind, but here too his impact on policy (the issuing of state licences to timber contractors and a $15 \%$ duty on all timber felled) was short lived, lasting barely two years. ${ }^{60}$

But, to Wallich, the interests of the Company and private capital were ultimately reconcilable. A common theme in his correspondence and reports was that India, so vast, so varied in climate and soil, ought, under proper direction, to be able both to meet the requirements of the state and support a substantial commercial trade in timber and other produce. In Awadh and Burma, he argued, in terms that could only favour further annexations, that there lay 'valuable treasures', vast stands of sissoo, teak and other trees that were being squandered by 'injudicious' felling: this would continue unless the Company intervened to regulate the forests and check exploitation. But he was equally convinced that Indian forests, suitable protected and 'harvested', could contribute to the international timber trade-to the Company's undoubted profit. As he told the Select Committee in 1832: 'No country on earth produces a larger or more valuable supply of timber than does India.' Although he warned of the imminent danger of a 'most painful falling off' in timber supplies, commerce, not conservation, dominated his thinking. ${ }^{61}$

${ }^{58}$ Seventh Report of the Plantation Committee, 6 January 1824 , BPC, nos. 25-28, 22 January 1824 ; N. Wallich to Secretary, General, 20 November 1827 , BPG, no. 57 , 14 February 1828.

${ }^{59}$ In his 1827 report on the Salween teak forests N. Wallich observed that the Company must act or else 'private enterprise will very soon render fruitless all its endeavours to perpetuate the supplies for the public service, and one of the principal and most certain sources of Revenue will thus be irrevocably lost': cited in H. Falconer, 'Report on the Teak Forests of the Tenasserim Provinces', Selections from the Records of the Bengal Government, vol. IX, Calcutta, Government of Bengal, 1852, 6.

${ }^{60}$ Ibid.

${ }^{61}$ N. Wallich, 13 August 1832 , 'Minutes of Evidence taken before the Select Commitee on the Affairs of the East India Company', 195-200. 


\section{Rare Plants and Indian Riches}

As we have already begun to see, Wallich repeatedly referred to the plant-life flora of South and Southeast Asia as 'riches' or 'treasures', terms suggestive of capitalist accumulation and exchange. ${ }^{62}$ It could be objected that this kind of phraseology, common enough among late eighteenth- and early nineteenth-century botanists, was simply indicative of the diversity, visual attractiveness and scientific interest of Asian flora and did not literally imply commercial value. However, the language of capitalism does seems appropriate to the manner in which Wallich approached botany and the ways in which plants from India and neighbouring territories came, especially during his superintendency at Calcutta, to be sought after, commodified and marketed. There is, though, an irony here. As already noted, following the famine of 1770 many British observers doubted whether, in its native flora or existing system of agriculture, India was particularly rich. Botanists came to see the plains of India as impoverished, largely devoid of new and interesting species. Their attention turned instead to those upland or forest areas on the margins of India proper, like Nepal and Burma, that early in the nineteenth century were opened up to Western science through the Company's military campaigns and diplomatic manoeuvres. These new areas offered a far more diverse and appealing flora, from the alpine and temperate species of Kumaon and Nepal to the tropical and semi-tropical vegetation of Burma, Assam and Sikkim.

There has been much discussion of imperial botany's role in serving the commercial and strategic interests of the colonial power (as by introducing rubber, cinchona and tea, and so laying the basis for colonial plantation economies), and certainly Wallich was involved in such enterprises, particularly as secretary of the Indian Tea Committee. But plantation crops were not the only keenly soughtafter plant commodities. Many species had horticultural appeal rather than agricultural or medicinal uses: they were of little commercial value to the Company, though they might augment its scientific prestige and patronage resources. Among the most prized were alpine and cool temperate plants from Nepal, 'that inexhaustible mine'

${ }^{62}$ As in his early correspondence with W. Hooker: N. Wallich to W. Hooker, 2 September 1818,13 October 1818 and 8 October 1819 , DG 52 . 
which Wallich regarded as 'one of the richest parts of India',63 and whose opening up to Western botany in the 1810 s and $1820 \mathrm{~s}$ (like that of Burma a decade later) constituted a vital stage in the exploration and exploitation of South Asia's plant bonanza. ${ }^{64}$ Many of these plants-including the species of clematis, primulas, ferns, magnolias and rhododendrons with which Wallich's name was closely associated-could be naturalized in European gardens, while others like the tropical palms of Southeast Asia could be taken up by British aristocrats for their hothouses and conservatories.

At Calcutta Wallich received and distributed vast numbers of living plants and seeds from India and adjacent regions. One illustration of this botanical largesse is the list of 190,000 plants (covering 690 genera and 1700 species) distributed from the botanic garden between 1836 and 1840 . The plants went not only to more than 2000 institutions and individuals, including other botanic gardens in India and abroad, government parks and buildings, but also, in keeping with Wallich's 'improving' ideals, to Indian zamindars, malis (gardeners) and civil servants. Others were despatched to aristocratic plant collectors in Britain-the dukes of Bedford, Derby, Devonshire and Northumberland figure repeatedly in his list. Wallich used these plants less to advance botanical knowledge than as a resource to win favours and encourage plant exchanges for the Calcutta garden and to gain personal recognition and influential contacts. ${ }^{65} \mathrm{He}$ was also, in the process, marketing India, in its broadest geographical sense, displaying and purveying its 'riches' to the West. As two German recipients aptly remarked on receiving his 'costly treasure', they were now 'as rich as Nabobs'. ${ }^{66}$

Wallich's engagement with plants as a form of personal and professional capital was further exemplified when he brought to London in 1828 the vast accumulation of dried plants he and other botanists had amassed through their travels and plant collecting over the previous quarter century. Packed into thirty crates, containing, by Wallich's estimation, 8 to 10,000 species, this was one of the largest plant hauls ever brought to Europe; Wallich privately boasted that

${ }^{63}$ N. Wallich to W. Hooker, 2 September 1818 , DG 52; N. Wallich to Secretary, Public, 8 April 1 820, BC F/4/655:18040.

${ }^{64}$ For Burma's 'botanical and horticultural riches', see N. Wallich to G. Lushington, 5 September 1827, BC F/4/1068: 29180.

65 'List of Plants', appended to N. Wallich's report to the Government of Bengal, 21 December 1840, BC F/4/1949: 84700.

${ }^{66}$ Quoted in Kumar, 'Evolution', 53. 
it even exceeded the number that the celebrated German naturalist Alexander von Humboldt had brought back from the Americas ${ }^{67}$ Like a returning 'nabob', Wallich deployed what rapidly became known as the Wallichian herbarium as a capital resource, not to gain money for himself (he was, he declared in $183_{2}$, as 'poor as a church rat'), ${ }^{68}$ but to enhance his scientific standing with the Company and secure the collaboration and recognition of naturalists throughout Europe. Ultimately, on his retirement from India, this plant hoard and the fame it won for its distributor helped secure him in 1849 the coveted position of Vice President of the Linnean Society, the scientific body to which the most complete set of the Wallichian herbarium had been entrusted, and in $185^{2}$ as Vice President of the Royal Society. ${ }^{69}$

Wallich's entrepreneurship thrived in an age in which the worldwide quest for rare and beautiful plants was burgeoning and where science and capitalism constantly colluded. It was not just the acquisitiveness that exotic herbaria inspired or living plants attracted-like 'his' Amherstia, the 'noble' flowering tree that both Kew Gardens and the Duke of Devonshire coveted, or the tropical palms that the Duke of Northumberland was eager to acquire for his glasshouse at Syon or even the phenomenal numbers of orchids pillaged from tropical and semi-tropical forests that passed through Calcutta en route to Europe. ${ }^{70}$ The material culture of nineteenth-century botany, including the published notices and pictorial representation of plants-so essential to botanical scienceitself became the site of a capital-intensive, technologically innovative, enterprise that spanned continents. ${ }^{71}$ The lavish and expensive works in which plants were so invitingly displayed in hand-coloured lithographed plates needed, even when in receipt of a Company

${ }^{67}$ N. Wallich to W. Hooker, 1 January 1828 , DC 43.

${ }^{68} \mathrm{~N}$. Wallich to W. Hooker, 27 June 1832 , DC 53.

${ }^{69}$ R. de Candolle and A. Radcliffe-Smith, 'Nathaniel Wallich and the Herbarium of the Honourable East India Company', Botanical Journal of the Linnean Society, 83, $1981,325-48$.

${ }^{70}$ Wallich identified several new species of orchids, and though not directly involved in their commercial collection and sale, his nephew, Charles Cantor, was: see 'A List of Terrestrial and Epiphytical Orchideae found in Assam and the Neighbouring Hills', May $185^{\circ}$, in N. Wallich to G. Bentham, 20 August $185^{\circ}$, Bentham Correspondence.

${ }^{71} \mathrm{On}$ the links between botany, visual culture and commerce, see J. B. Hochstrasser, 'The Conquest of Spice and the Dutch Colonial Imaginary: Seen and Unseen in the Visual Culture of Trade', in L. Schieberger and C. Swan (eds), Colonial Botany, 169-86. Wallich's Tentamen Florae Napalensis Illustratae (Serampore, Asiatic Lithograph Press, 1826) was one of the first lithographic works produced in India. 
subsidy, substantial funding and energetic marketing. A flyer inviting subscriptions for Wallich's Plantae Asiaticae Rariores pointed to the paucity of illustrated works on Indian plants, contrasting this dearth with a flora that 'yields to none, either as regards the numerical extent and variety, or the beauty and utility of its plants'. The three volumes, each of 100 pages, were to appear first in twelve parts, with 25 engravings apiece, at three monthly intervals, costing $£_{2-1}$ os each or $£_{3}$ o for the complete set. ${ }^{72}$ The success of this publishing strategy (not uncommon for costly botanical works at the time) was evident from the opening pages of the Plantae with a long list of royal, aristocratic and scientific subscribers, including a number of Indians. ${ }^{73}$

Wallich's Plantae surely ranks technically and scientifically among the highest achievements of the Company period. It is a work that not only attests to the power of botanical art and visual culture in the joint service of science and empire, but also is expressive of the hierarchical nature of scientific endeavour and the multiple authorial strategies involved by the early nineteenth century in producing a work of Asian botany. ${ }^{74}$ Its publication in London by a German publisher, principally for a Western audience, along with the arrival of the Wallichian herbarium, underscored the importance of bringing Asian plant lifeas a kind of floral tribute-to the imperial metropolis. Although it appeared under Wallich's name, the Plantae was the product of collaborative enterprise. Apart from plants personally collected by Wallich in Nepal and Southeast Asia, it included many gathered by other naturalists, including Buchanan, and plant collectors from Calcutta. The glorious colour plates-more than $25^{\circ}$ of them-were mainly the work of two Indian artists, Vishnuprasad and Gorachand, based at the Calcutta garden and trained in Western techniques, though supplemented, in Calcutta and London, by the labours of European botanists, draftsmen and lithographers. Like other botanical illustrations of the period, the plates suggest a dynamic tension

${ }^{72}$ N. Wallich, 'Proposals for Publishing by Subscription... Plantae Asiaticae Rariores', December 1828 (British Library).

${ }^{73}$ N. Wallich, Plantae, vol. 1 , xiii.

${ }^{74}$ For the composition of earlier texts, see K. Raj, 'Surgeons, Fakirs, Merchants, and Craftspeople: Making L'Empereur's Jardin in Early Modern South Asia', in L. Schiebinger and C. Swan (eds), Colonial Botany, 252-69; R. Grove, 'Indigenous Knowledge and the Significance of South-West India for Portuguese and Dutch Constructions of Tropical Nature', Modern Asian Studies, 30: 1, 1996, 12 1-43. 
between Indian artistry and aesthetics and Western expectations of scientific accuracy and objectivity. ${ }^{75}$

The Plantae was a collaborative work, too, in the sense that, like many botanical works of the period in India, it embodied fragments of indigenous knowledge-from vernacular plant names to the local uses of plants as food, medicines, dyes and timber-though 'native' usage was repeatedly contextualised by invoking the superior understanding of Western botany and by comments on the potential (but as yet unrealised) commercial utility of plants or the defective nature of indigenous practices (e.g., in properly seasoning timber) ${ }^{76}$ Indigenous knowledge, while adding to Wallich's authorial stature as an observant and enquiring traveller, was strictly subordinated to Western plant science. ${ }^{77}$ Moreover, in the Plantae, as in his earlier study of Nepalese flora, Wallich's superior powers of appraisal ranged well beyond local usage or even agricultural utility. Plants were presented as 'objects' of pleasure and desire-as 'charming', 'stately', 'beautiful' and 'superb'-whether in their flowers, foliage or overall form and appearance. Through the combination of illustration and text, their physical attractiveness and rarity was raised, beyond scientific scrutiny and taxonomic exactitude, into the realms of aesthetics and avarice. Wallich courted this acquisitiveness, indicating how plants, such as magnolias and rhododendrons native to Nepal, might endure cold European winters, while others were well suited to the heated glasshouses then becoming fashionable in Europe. ${ }^{78}$

The Plantae reveals Wallich's attitudes and ambitions in other ways, too. In his preface and in the commentary accompanying each plate, Wallich acknowledged the many personal favours and professional debts he had accumulated during his career-his

${ }^{75} \mathrm{H}$. Noltie, 'Robert Wight and the Illustration of Indian Botany', The Linnean, special issue, no. 6, 2006, 22-3. In 1827, seeking a pay increase from Rs 35 to Rs 60 a month for Vishnuprasad (a Brahmin who had previously worked on Buchanan's Bengal survey before joining the Calcutta garden), Wallich remarked that his current wage was 'entirely inadequate for his skill, which ... is not equalled among the Natives of this country and rarely exceeded by any botanical draftsmen in Europe': N. Wallich to C. Lushington, 5 September 1827, BG F/4/1068: 29180. But such high praise was not for European consumption. In presenting the Plantae to a Western audience, Wallich blamed 'any imperfections' in the plates on their being drawn by Indian artists: N. Wallich, Plantae, vol. $1, \mathrm{x}$.

${ }^{76}$ N. Wallich, Plantae, vol. 1, 9-12, 35-7, 40-1.

${ }^{77}$ For the growing distinction between Western, text-based botanical science and indigenous, oral plant knowledge, see L. Schiebinger and C. Swan, 'Introduction', 10.

${ }^{78}$ N. Wallich, Plantae, vol. 1, 38, 44; vol. 2, 78; N. Wallich, Tentamen, 1, 39. 
teachers in Copenhagen, the Court of Directors, Calcutta patrons, fellow botanists in India, the taxonomists who had helped classify the thousands of specimens brought to London. ${ }^{79}$ These profuse expressions of friendship and gratitude gave the Plantae a further transactional character; only, instead of money, patrons and professionals were rewarded for past favours with flattering tributes or the naming of rare and beautiful plants in their honour. In deploying the botanical 'riches' of South and Southeast Asia in this way, as a capital resource, Wallich was building further professional and patronage ties and identifying himself with the leading naturalists of the age; no such praise and deference were directed towards Indians of whatever social rank or scientific aptitude. Similarly, although not all the plants were Wallich's own 'discoveries', many were woven into a narrative of his travels, thereby rendering a work dedicated to describing Asian flora into a semi-autobiographical tract and a statement of the author's personal contribution to the heroic task of botanical reconnaissance.

To take a prime example, the first volume of the Plantae opened with two illustrations of Wallich's prize find, the Amherstia nobilis. This spectacular flowering tree was brought to Wallich's attention when he visited Burma in 1826-1827. Previously unknown to Western botany and rarely found in the wild, it was sighted in the compound of a temple where its geranium-coloured flowers were presented as offerings to the Buddha. Wallich had cuttings taken and transferred to the Calcutta garden, where 'his' Amherstia first flowered ten years later. In the Plantae Wallich noted its Burmese name and provenance, but took credit for bringing it to botanists' attention and for endowing it with its specific name, Amherstia, given in honour of the Governor General's wife and daughter: they were both keen botanists, but in honouring them he was also immortalizing Lord Amherst by his association with such a remarkable tree. ${ }^{80}$ Even though credit for finding this spectacular plant more properly belonged to Burmese monks and worshippers, to Wallich accrued the kudos of its discovery and dissemination. ${ }^{81}$

${ }^{79}$ In his Preface (Plantae, vol. 1, ix) Wallich identified 28 botanists who had assisted him with the identification of plants; other names-including non-botanists-appear in the text: e.g., vol. 1, 28-9, 57, 72.

${ }^{80}$ N. Wallich, Plantae, vol. 1, 2-3.

${ }^{81}$ Even drawings of the Amherstia were greatly prized: N. Wallich to W. Hooker, 3 January 1828 , DC 43 . 


\section{Science, Circulation and the Hierarchy of Knowledge}

Being a naturalist in early nineteenth-century India was an uneasy mixture of opportunity and disadvantage. Some of the drawbacks of a scientific career there have already been alluded to-they ranged from the difficulty of gaining the attention of metropolitan science and the erratic patronage and financial constraints of the Company to the likelihood of dying even earlier than in Europe. To these could be added the adversity many Company scientists felt from the paucity of reference works, the lack of technical and taxonomic expertise and even the difficulty of protecting specimens against India's humid climate and voracious insect life. ${ }^{82}$ But, to the resolute and ambitious naturalist, India also offered unique opportunities and a more secure scientific base than was to be found in almost any other colonial location at the time.

One of the advantages of being based in India was the chance to travel and to botanise in areas rich in plant life but previously unknown to Western science. ${ }^{83}$ Having had few previous opportunities for botanical travel, Wallich was quick to seize the opportunity created by his confirmation as superintendent in 1817 . The Calcutta garden had already acquired 'numerous and valuable additions' from Nepal-through the travels of Francis Buchanan, from plants sent by the British Resident, Edward Gardner, and from itinerant plant collectors. $^{84}$ In July 1820 the Government of Bengal acceded to Wallich's request to visit Nepal in person to add to the existing 'riches' in the Calcutta garden through 'the discovery of new and interesting objects of Agriculture [and] Horticulture'. The government gave him an additional allowance for his journey and for a 'travelling

${ }^{82}$ D. Arnold, Tropics, 166-72.

${ }^{83}$ A substantial considerable literature now exists on scientific travel: in particular, see J. R. Camerini's articles: 'Remains of the Day: Early Victorians in the Field', in B. Lightman (ed.), Victorian Science in Context, Chicago, IL, 1997, 354-77, and 'Wallace in the Field', in H. Kuklick and R. E. Kohler (eds), 'Science in the Field', Osiris, 11 , $1996,44-65$.

${ }_{84}$ Including Bharat Singh, 'an intelligent and respectable Brahmin', who had previously assisted Buchanan in Nepal and the Sunderbans. 'It is to the rare knowledge of this man that both Dr Buchanan and myself owe the discovery of a large proportion of valuable trees and plants': N. Wallich to Secretary Public, 25 September 1817 , BC F/4/621: 15534. But Bharat Singh and the many other 'Brahmins' who served Wallich received scant mention in his European writings. 
establishment' of plant collectors, malis and painters. ${ }^{85}$ Granted a year's leave, Wallich obtained a five-month extension to allow him to stay in Nepal during the rainy season of 1821 , a time when the vegetation would be at its most 'luxuriant' and the countryside richest in 'vegetable productions'. ${ }^{86}$ Although prolonging his stay adversely affected Wallich's health-the 'slow and racking torture' of the malaria he caught in 1822 and which troubled him for the rest of his life ${ }^{87}$-and although the Nepalese authorities would not allow him to travel beyond the Kathmandu valley, Nepal gave Wallich the authority of having travelled and collected in one of the world's most spectacular plant provinces. Along with his expedition to Burma a decade later, Nepal helped secure Wallich's international reputation and gave him sufficient capital-in terms of plant specimens and drawings-to sustain his subsequent career.

Not all botanists were so fortunate or so well able to turn their Indian employment to such good effect. In 1826 Wallich endorsed a request from George Govan, who had preceded Royle as the superintendent of the Saharanpur garden, to botanise in the western Himalayas. Wallich enthused over the benefits to the Company and to science of exploring the flora of that 'glorious' mountain range and the 'general desire to become nearer acquainted with the vegetable treasures of those hitherto so little known, and yet so immensely interesting regions' ${ }^{88}$ But the government declined: Govan was too valuable in his current post - in charge of the military hospital at Barrackpore-to be spared and his promising botanical career came to a standstill. ${ }^{89}$ By contrast, Wallich's ability to travel-in effect, to circulate-and to move along with his plant specimens and drawings within South and Southeast Asia and between India and Europe was one of the principal assets of his early and middle career.

However, reference to the Himalayas directs us to a less advantageous aspect of Wallich's scientific career. One of the arguments he made in Govan's support was the need to examine the flora of a mountainous region in which the effects of elevation and climate on the nature and distribution of plants could most fully

${ }^{85}$ N. Wallich to Secretary, Public, 8 April 1820 ; Public Letter from Bengal, 31 July $1820, \mathrm{BC} \mathrm{F} / 4 / 655: 18040$.

${ }^{86} \mathrm{~N}$. Wallich to Secretary, Public, 4 July 1821 , in ibid.

${ }^{87}$ N. Wallich to W. Hooker, 14 June 1820 , DC 43.

${ }^{88}$ N. Wallich to Secretary, Public, 12 May 1826, BC F/4/955: 27123 (2).

${ }^{89} \mathrm{H}$. Montgomery Hyde, 'Dr George Govan and the Saharanpur Botanical Gardens', Journal of the Royal Central Asian Society, 49: 1, 1962, 47-57. 
be investigated. This argument-and the accompanying comparison between the Himalayas and Andes-is one indication among many that Wallich was well aware of Humboldt's pioneering studies of plant geography. ${ }^{90}$ Wallich also exchanged bio-geographical ideas with the man who did what Govan was unable to do-J. F. Royle in his Humboldtian account of the flora of the western Himalayas, published in $1839 .{ }^{91}$ But, whether for want of aptitude or (more likely in view of his many official responsibilities) time, Wallich never metamorphosed into a 'philosophical' botanist. ${ }^{92}$ Perhaps, he was over-awed by Humboldt's achievements. In 1828, describing the vast haul of plants he was taking to England, Wallich compared his Indian collection with the smaller number of plants Humboldt had gathered during his South American journey. 'Alas', he added, 'the comparison durst go no further. Humboldt and Wallich-an Oak and a Nightshade, a Lion and a Mouse: Atlas and a Molehill'. ${ }^{93}$ Certainly Humboldt's scientific reputation and his bio-geographical ideas circulated widely in early nineteenth-century India, but Wallich failed to engage with this 'philosophical', rather than empirical and economic, trend in botanical science. Coupled with his eagerness to satisfy the Company's material interests and to bring his rich 'harvest' of Indian species to the attention of Western plant lovers, this lacuna ultimately diminished his scientific reputation. Even before his death in $185^{6}$, he was being remembered more for his plant collecting and herbarium than for any original contribution to scientific botany. ${ }^{94}$

${ }^{90}$ R. H. Grove (Green Imperialism, 359, 375) suggests that Wallich was unaware of Humboldt's desiccation arguments and so failed to make a more scientific case for forest conservation in India. He may have ignored desiccationism, but was hardly unaware of Humboldt.

${ }^{91} \mathrm{~J}$. Forbes Royle, Illustrations of the Botany and Other Branches of the Natural History of the Himalayan Mountains and of the Flora of Cashmere, London, W. H. Allen, 1839. For the Royle-Wallich correspondence, see BC F/4/955: 27123 (3).

92 Cf. T. Thomson, 'Notes on the Herbarium of the Calcutta Botanical Garden', Journal of the Asiatic Society of Bengal, 25: 5, 1856, 414 .

${ }^{93} \mathrm{~N}$. Wallich to W. Hooker, 1 January 1828 , DC 43 . References to Humboldt are sparse in the Plantae: the only plant named in his honour (Humboldtia brunonis) was one so designated by Wallich's 'revered preceptor', Martin Vahl, and shared with the 'equally illustrious' Robert Brown: N. Wallich, Plantae, vol. 3, 18.

${ }^{94}$ See the guarded references to N. Wallich in the 'Introductory Essay' to J. D. Hooker and T. Thomson, Flora Indica, London, W. Pamplin, 1855 . Note, too, the almost complete absence of Wallich from Darwin's massive correspondence. The marine biology of his son, George Wallich, was of much greater interest: see F. Burkhardt 
Wallich's Indian career falls into three phases-thirteen years from his first appointment to the Calcutta garden in 1815 to his departure in 1828 , followed by four years in London (1828-1832), and a final phase, $1833^{-1} 846$, back in Calcutta, in which he was an increasingly marginalised figure. In part, Wallich's decline can be explained by his incapacitating ill health and by the financial curbs imposed on the botanic garden in Calcutta in 1828 , just at the time when he left for London and from which it took decades to recover. But to more fully explain his decline we need to return to the heated disputes that punctuated Wallich's professional life and which, by the end of it, came close to ruining his scientific reputation. His nemesis was a young surgeon-naturalist, William Griffith. Wallich first encountered Griffith as a medical student at University College London, studying botany under John Lindley. Impressed by his 'extraordinary talents' as a plant anatomist and draftsman, Wallich celebrated Griffith's abilities in the last volume of the Plantae. ${ }^{95}$ When Griffith was appointed to Madras as an assistant surgeon, Wallich sought to advance his career, as he did that of many other botanists in India, and helped to secure science-friendly postings for him. But the relationship soon soured and became so bitterly divisive that it split European naturalists in India into two opposing camps.

A key episode in the deteriorating relationship came when Wallich, Griffith and another surgeon-naturalist, John M'Clelland, were sent to Assam in July 1835 to report on indigenous tea plants. Griffith, by this time a much-travelled botanist, felt that Wallich was determined to prevent him from collecting any new plants (even destroying those he did collect), or wanted, as the senior botanist, to claim such novelties for himself. By M'Clelland's account, Wallich was so preoccupied with his health that he was anxious to complete their mission as quickly as possible and return to the relative safety of Calcutta. Wallich appears in this narrative as selfish, petulant and 'theatrical': 'to be on good terms with him', Griffith snarled in his diary, 'one must pay him continual and excessive court' ${ }^{96}$ Within days Wallich and Griffith were barely talking to each other and Griffith took the first opportunity to escape from this 'bondage' to botanise by himself in Assam. The two

and S. Smith (eds), The Correspondence of Chares Darwin, vol. VIII, Cambridge, England, Cambridge University Press, 1993, 526, 528-30.

${ }_{95}$ N. Wallich, Plantae, vol. 3, v, 11.

${ }^{96}$ J. M'Clelland, 'Memorandum Regarding the Differences Between Dr Wallich and the Late W. Griffith', June 1848 , RBG Library. 
men soon became embroiled in an acrimonious dispute as to whether there were two species of tea plants (rather adversarially designated Camellia caudata Wall. and Camellia theifera Griff.) or only one. Skilled in microscopy and plant anatomy, Griffith was best placed to win the argument. ${ }^{97}$

The dispute escalated in 1842 when Wallich departed on sick leave for South Africa, and Griffith (replacing Wallich in Lord Auckland's favour, a shift which Wallich regarded as betrayal) ${ }^{98}$ was given temporary charge of the Calcutta garden. One might as well have put a vegetarian in charge of a slaughter house. Griffith felled many of the finest trees in the overgrown garden and cut down the avenue of cycads that had been one of its principal glories. He began a new series of gardens to show the classification of plants, one exemplifying the Natural System, another the old Linnaean system. ${ }^{99}$ Griffith further infuriated Wallich by adding 'offensive' notes to the superintendent's private letter book. ${ }^{100}$ While personal animosity fuelled this conflict, a vital element was the different professional approach to botany the two men exhibited. By the 183 os the Linnaean system of classification, based on the sexual parts of plants, was being superseded, even in India, by the Natural System grounded, far more scientifically, in the shared family characteristics of plants. ${ }^{101}$ Wallich was a Linnaean of the old school-one of the accomplishments that had won him the superintendency in the first place-but he was slow to adopt the new classificatory system, requiring others, such as Royle in London, to identify plants for him according to the Natural System. ${ }^{102}$

${ }^{97}$ W. Griffith, 'Report on the Tea Plant of Upper Assam', BC F/4/1 7og: 69o24.

${ }^{98}$ For Wallich's animosity to Auckland, see N. Wallich to W. Hooker, 8 February 1853 , DC 55 .

${ }_{99}$ For Griffith's legacy, see J. M'Clelland, 'Report on the Hon'ble Company's Botanic Garden at Calcutta', 7 November 1846, BC F/4/2219: 110061 ; 'Extracts from the Private Letters of Dr J. D. Hooker', Hooker's Journal of Botany, vol. 1, 1849, 4-5.

${ }_{100}$ N. Wallich to G. Bentham, 28 August 1848, Bentham Correspondence.

${ }^{101}$ Among the first works of South Asian botany to employ the Natural System were D. Don, Prodromus Florae Nepalensis (1825) and R. Wight and G. A. Walker Arnott, Prodromus Florae Peninsulae Indiae Orientalis (1834). One advantage of the Natural System was that it enabled botanists in India to anticipate that plants belonging to a family already well-known in Europe might possess the same properties in South Asia (for example, as medicinal drugs): J. F. Royle, An Essay on the Antiquity of Hindoo Medicine, London, W. H. Allen, 1837, 5-6; W. B. O'Shaughnessy, The Bengal Pharmacopoeia and General Conspectus of Medicinal Plants Arranged According to the Natural and Therapeutic Systems, Calcutta, Bishop's College Press, 1844 , v.

102 'Wallich Catalogue: Arranged in Natural Orders by J. F. Royle', December 1829 , RBG Library. However, the evidence on Wallich's familiarity with the Natural System 
In the eyes of a Young Turk (and 'philosophical botanist') like Griffith, Wallich was not only a poor botanist, but also a living anachronism who had failed to keep pace with the circulation of new scientific ideas and techniques. During the tea expedition, Griffith noted, in cataloguing Wallich's many failings, 'Every thing I have said in jest, he has taken in earnest. My way of talking of Linnean Botanists he construes into a personal insult'. ${ }^{103}$ It is not surprising that Wallich, twice Griffith's age and racked by ill health, saw little humour in this constant harping on his professional deficiencies. ${ }^{104}$ Since the 1820 s the botanic garden had suffered under-funding and neglect, but Griffith's grubbing up and redesigning of Wallich's garden-his 'pet'-was understood by the ageing superintendent as a gesture of undisguised contempt. But it also epitomised a conflict, as M'Clelland put it, between 'Science and mere ornamentation'. ${ }^{105}$ Griffith died shortly after, but Wallich lived for another nine years. While he remained in post he fiercely contested the posthumous publication of Griffith's work at the Company's expense and with artists (including Luchman Singh, the head painter) filched from his own staff, but on both issues he was overruled. ${ }^{106}$ By the 1840 os it had become the fashion to 'deprecate' Wallich's botanical work, a trend some sympathetic naturalists saw as purely 'malicious' and 'dictated by personal hostility'. ${ }^{107}$ But in keeping this bitter and divisive dispute alive, ${ }^{108}$ Wallich sought vindication for his achievements and status as India's premier botanist-recognition that he eventually gained by being elected Vice President of the Linnean Society in 1849 .

is confusing. The plants he brought back from Nepal in 1822 were said to have been arranged according to the Natural System (presumably but not necessarily by Wallich himself), except those of 'doubtful affinity': N. Wallich to C. Lushington, 21 January $1822, \mathrm{BC} \mathrm{F} / 4 / 712: 19459$.

${ }^{103}$ W. Griffith's journal, 17 February 1836 , cited in M'Clelland, 'Memorandum'.

${ }^{104}$ Wallich's 1840 list of plants (BC F/4/1949: 84700) distributed from Calcutta used the Natural System throughout, suggesting that by then Wallich had fully learned its use.

${ }^{105}$ J. M'Clelland, 'Report', BC F/4/22 19: 110061.

106 N. Wallich to Under Secretary, Public, 25 August 1845, BC F/4/2 188 : 106999.

107 [William] Madden, 'The Turaee and Outer Mountains of Kumaoon', Journal of the Asiatic Society of Bengal, 17:1, 1848, 418 .

${ }^{108} \mathrm{~J}$. Hooker claimed that Griffith (whom he never met), Wallich, M'Clelland were 'the three most ill-tempered fellows in all India \& most sure to quarrel, that could anywhere be found'. He also believed that Wallich had made himself 'thoroughly odious' in India as a result of this dispute: J. Hooker to W. Hooker, 10 March 1849 , 11 April 1849, Hooker's Indian Letters, RBG. 


\section{Conclusion}

While some recent scholars see Wallich as farsighted, even a 'genius', it is clear that contemporary opinion was more cautious and divided. Wallich's judgement on himself, made in 1830 , that he only aspired to be a 'faithful pioneer and collector in the field of Indian Botany', 109 might be a display of false modesty, inviting contradiction, but perhaps it accurately summarised his scientific ambitions. His was a career fraught with contradiction. His long tenure of one of the most prestigious posts available to a scientific servant of the East India Company owed much to his multiple identities: as an itinerant plant collector and enthusiastic 'improver', as a botanical entrepreneur who made the 'riches' of Indian plant life known and accessible to Europe, as a loyal employee who assiduously served the Company's material interests in forestry and botany and (until the 1840s) as an effective operator in the patronage politics that surrounded Indian botany. His career shows how much the pursuit of botany as a colonial science was bound up with the practical and ideological needs of the Company, with plants as a kind of capital, essential for personal and professional advancement, both in India and in Europe. For two decades Wallich was remarkably successful, and yet, in his twilight years, he cut a rather provincial figure, out of touch with the latest scientific trends, not just in the metropole but even, as Griffith cruelly reminded him, in India itself. Wallich may in some respects have been an exceptional figure in the history of Company science, but in his attachment to plant capitalism he was an exemplary one.

\section{Acknowledgements}

I am grateful to those who commented on that and other drafts, especially Henry Noltie, Ib Friis and Michael Sterll, and to Chris Fraser-Jenkins. Research has been greatly aided by Richard Axelby and Savithri Preetha Nair at the British Library and by the archivists and librarians at Kew. 